The Classical Quarterly 70.1 27-42 (C) The Classical Association (2020). This is an Open Access article, distributed under the terms of the Creative Commons Attribution licence (http://creativecommons.org/licenses/by/4.0/), which permits unrestricted re-use, distribution, and reproduction in any medium, provided the original work is properly cited.

\title{
HERACLES' ITCH: AN ANALYSIS OF THE FIRST CASE OF MALE UTERINE DISPLACEMENT IN GREEK LITERATURE**
}

Scholars have long grappled with the nature of Heracles' vóбoৎ and his consequent feminization in Sophocles' Women of Trachis (= Trachiniae). ${ }^{1}$ Despite being triggered by a poisonous garment, ${ }^{2}$ which acts by means of magic incantation, the evolution of Heracles' symptoms is described as a clinical case. Yet, making sense of his feminization from a scientific perspective has proven hard. ${ }^{3}$ In this paper, I investigate the symptoms experienced by Heracles, which Sophocles generically refers to as vóбoc. The first part focusses on Sophocles' description of erôs as a disease in Trachiniae. I then move on to dividing Heracles' symptoms into two categories, which I will call vó $\varsigma^{\prime} \varsigma_{1}$ and vóøo $\varsigma_{2}$. The erotic passion for Iole which Heracles naturally experiences in the first part of the tragedy will be denoted by vó $\sigma 0 \varsigma_{1}$, whereas vó $\sigma 0 \varsigma_{2}$ will refer to the

* I wish to express my gratitude to Professor Gábor Betegh, Dr Sophia Connell, Dr Sean Coughlin, Dr Tiziana D'Angelo, Professor Patrick Finglass and the anonymous referee for their very helpful comments on this paper.

${ }^{1}$ P. Biggs, 'The disease theme in Sophocles' Ajax, Philoctetes and Trachiniae', CPh 61 (1966), 22335 , at 228 underlines how Heracles' disease deprives him of his humanity and condemns him to isolation. N. Loraux, The Experiences of Tiresias: The Feminine and the Greek Man (transl. P. Wissing) (Princeton, NJ, 1997), 40 claims that Heracles' pains are those typical of women in childbirth; C. Faraone, 'Deianira's mistake and the demise of Heracles: erotic magic in Sophocles' Trachiniae', Helios 21 (1994), 115-35 considers Heracles' feminization to be one of the predictable side effects of Deianira's erotic magic; C. Segal, Sophocles' Tragic World: Divinity, Nature, Society (Cambridge, MA, 1995), 55 claims that 'the fire that kindled the poison of the beast' has 'reduced Heracles to almost bestial status'. F.I. Zeitlin, Playing the Other: Gender and Society in Classical Greek Literature (Chicago, 1996), 350 explains how Heracles' condition of weakness makes him aware that he has a body, and makes him perceive himself 'to be most like a woman'. G. Ceschi, 'Il caso clinico di Eracle nelle Trachinie di Sofocle', Atti dell'Istituto Veneto di scienze, lettere ed arti: Classe di scienze morali, lettere ed arti 161 (2003), 65-93 considers Heracles' disease a pulmonary pathology. According to C. Thumiger, 'Mad Erôs and eroticized madness in tragedy', in E. Sanders, C. Thumiger, C. Carey and N.J. Lowe (edd.), Erôs in Ancient Greece (Oxford, 2013), 27-40, at 35, Heracles' vóбos 'has much to share with the standard phenomenology of erôs'.

2 The garment plays a crucial role in the development of the plot: not only is it the robe that prompts Heracles' torments, it is often described as a female garment that prompts Heracles' feminization. V. Wohl, Intimate Commerce: Exchange, Gender, and Subjectivity in Greek Tragedy (Austin, 1998), 195 n. 20 notices how the robe is repeatedly referred to as a peplos (602, 613, $674,758,774)$ and how it is emphasized as a feminine robe $(602,764)$. Loraux (n. 1), 130 stresses how the peplos in the tragedy 'serves as well to dramatize the exchange between masculine and feminine that takes place in the hero'. K. Cawthorn, Becoming Female: The Male Body in Greek Tragedy (London, 2008), 85-6 points out how the peplos catalyses and emphasizes Heracles' feminization.

${ }^{3}$ Loraux (n. 1), 40 claims that Heracles is here experiencing the pains of a woman in childbirth, yet admits that 'One could probably object ... that Herakles does not suffer in his belly, the feminine site of odunai, but in his side.' D. Pozzi, 'Deianira's robe: diction in Sophocles' Trachiniae', Mnemosyne 47 (1994), 577-85, at 584 considers that 'Heracles' male body being penetrated by the erotic and deadly pharmakon' smeared by Deianira represents a 'gender reversal' in the tragedy. Cawthorn (n. 2), 91 points out that Heracles becomes female through his sufferings, which are caused by a woman. 
magic-induced symptoms from which he suffers in the second and final part. In the final section of the paper I will seek to provide a scientific explanation for vó $\sigma 0 \varsigma_{2}$ and, ultimately, to describe the medical reasons behind Heracles' feminization.

Sophocles' Trachiniae opens with a quest for Heracles. His wife Deianira is searching for him, and asks the messenger about the whereabouts of her husband. We soon learn about the favourable outcome of Heracles' last military deeds, yet the tone of the play soon darkens. His passion for young Iole has taken control of his mind and led him to destroy the city of Oechalia, postponing his return home (351-68). Determined to get her husband back, Deianira resorts to an extreme remedy. She follows the advice given to her by Nessus before his death, and sends her garment-soaked in the blood of the Centaur-as a gift to her husband (600-19). Although Deainira's hope is to revive Heracles' longing for her, the outcome could not be further from her wish. Nessus has deceived her, and his blood proves to be poisonous and lethal. As a consequence, Heracles is plagued by a series of atrocious torments, culminating in his feminization (1075) and, eventually, his death (1259-78).

The play is built around the well-known theme of Heracles' contradictions. A great warrior fighting against monstrous beasts, yet displaying an innate ferity himself, a wellknown womanizer, yet linked to a tradition of transvestism, Heracles' complex persona has long puzzled scholars. ${ }^{4}$ In Trachiniae the antithetical facets of his character are brought together by the vó $\sigma 0 \varsigma,{ }^{5}$ which seizes his mind and his body. This itself constitutes another of the long series of contradictions, in that the valorous hero, known for his strength, is yet so prone to disease as to be linked to several literary traditions on the topic. $^{6}$ As Sophocles refers to Heracles' agony as vóøos, which is also the term he uses to describe the effects on him of erôs in the first part of the tragedy, I shall first seek to analyse Sophocles' views on erotic feeling, as shown in Trachiniae.

\section{SOPHOCLES' NOTION OF ERÔS IN TRACHINIAE}

At the outset of the tragedy, while describing Heracles' prolonged absence, Deianira talks

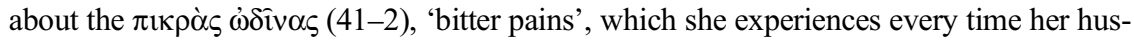
band is far from home. This is the first mention of physical pain owing to erotic feeling in the tragedy. Although Deianira expresses her longing for her distant husband through physical suffering, the word vó $\sigma o \zeta$ is not employed in this specific case. Deianira will end up causing Heracles' death and her own, yet she is not in the grip of erotic disease- even though her

\footnotetext{
${ }^{4}$ See W. Burkert, Structure and History in Greek Mythology and Ritual (Oakland, 1979), 79, 83, 96; also Loraux (n. 1), 118-22. C. Segal, Tragedy and Civilization: An Interpretation of Sophocles (Norman, OK, 1999), 61 stresses in particular the contradiction between Heracles' civilizing force, which earns him a divine honour, and his excessive appetites, which relocate him in a wholly human, if not feral, dimension. See also P.E. Slater, The Glory of Hera: Greek Mythology and the Greek Family (Princeton, NJ, 1968), 388; Cawthorn (n. 2), 83.

${ }^{5}$ C. Segal, 'Sophocles' Trachiniae: myth, poetry, and heroic values', in T.F. Gould and C.J. Herington (edd.), Greek Tragedy (Cambridge, New York and Melbourne, 1977), 99-158, at 113-14 stresses how the notion of disease changes from the first to the second part of the tragedy. Whereas at first it is categorized as erotic passion, it becomes more sinister and nefarious - a 'destructive physical power'.

${ }^{6}$ See H. von Staden, 'The mind and skin of Heracles', in D. Gourevitch (ed.), Maladie et maladies: Historie et conceptualisation, hautes études médiévales et modernes (Geneva, 1992), 131-50.
} 
emotions are intense, she seems aware of the nefarious consequences of erotic madness, and willing to address them rationally $(490-2){ }^{7}$

The same cannot be said of Heracles. Since his first association with erotic feeling in the play, he appears to be deeply immersed in turbulent emotions. In line 368 he is said

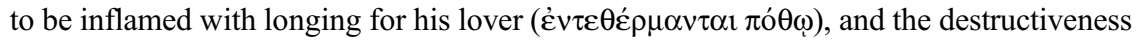

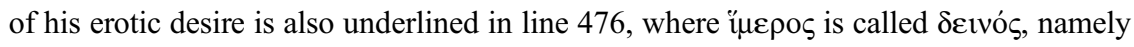
'terrible'. Heracles' passion for Iole is said to have total control over the mighty hero, who, while excelling in all his toils, is now vanquished by his lust for a woman (489). His erôs is expressed through the keyword vóøos (544), which signifies that Heracles' feelings have reached a different level, taking hold of him as a disease would do. ${ }^{8}$

Along with its harmfulness, Sophocles stresses another distinctive feature of erotic feeling-it is an ineluctable force, which appears to be independent of the will of the individual. Thus in lines 445-8 Deianira claims that her husband is innocent, as he is moved by Erôs and acting accordingly. Even Iole, the rival woman, is not to blame. Neither is ultimately responsible for Heracles' vó $\sigma o \varsigma$, as Deianira states in lines 543-4:

I do not know how to be angry with my husband now that he is suffering severely from this

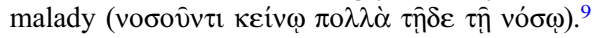

The essence of erotic illness resides in the somatization of the feeling itself, and in the symptoms that it causes, which affect the mind along with the body. ${ }^{10}$ Heracles is said to be totally absorbed by his passion for Iole (476-8), to the point that he destroys her native city to possess her. Nevertheless (543-4), Deianira shows sympathy for Heracles' condition-she cannot blame her husband for what he is experiencing. His behaviour is due to a disease (vó $\sigma \circ \varsigma$ ), which is causing him severe pain.

Thus, even before the real tragedy takes place on stage, Sophocles explicitly claims that Heracles is afflicted by a pathological condition. The garment has not been in contact with his skin; nevertheless, Heracles is already suffering from a vó $\sigma 0 \varsigma$ - this is how Sophocles refers to his passion for Iole. This last point is worthy of further analysis. It is her awareness of Heracles' condition that will induce Deianira to take action and to procure the enchanted robe. We are almost at the end of the first half of the tragedy (600-19), and at the very heart of the development of events. To stress the subtle, bitter irony that permeates his work, Sophocles makes us aware of the reasoning behind Deianira's decision. Once she ascertains her husband's vóбos, she seeks to rescue him and secure his love again, although, by doing so, she will end up condemning Heracles to his death.

\footnotetext{
${ }^{7}$ As pointed out by Thumiger (n. 1), 34-5, Erôs in the whole tragedy is consistently conceived as a madness-bringer. Ironically, the sole apparent exception to this rule, the character of Deianira, whose erôs is 'matured through the years, reflective, controlled', is the one who ends up committing the most foolish deed in the whole play.

${ }^{8}$ Lovesickness has a long-standing literary tradition: see e.g. Sappho, fr. 31.5-16 Voigt; Eur. Hipp. 38-40; P1. Symp. 185e-188e. However, we do not find any mention of it in Hippocratic texts, which still deal with sexual desire and deem moderate sexual intercourse necessary to prevent diseases in men and, particularly, in women: see L. McNamara, 'Hippocratic and non-Hippocratic approaches to lovesickness', in L. Dean-Jones and R.M. Rosen (edd.), Ancient Concepts of the Hippocratic. Papers Presented at the XIIIth International Hippocrates Colloquium, Austin, Texas, August 2008 (Leiden and Boston, 2016), 308-27, at 317-22.

9 All the translations from Sophocles' Trachiniae, unless stated otherwise, are by H. Lloyd-Jones (Cambridge, MA and London, $1998^{2}$ ).

${ }^{10}$ Compare the news that the messenger brings about the destruction of the city of Oechalia, and how Heracles' erotic passion, and not Iole, was responsible for it (431-3).
} 
Heracles appears to be affected by two distinctive vóøor, both caused by women, to which I will refer from now on as vó $\sigma 0 \varsigma_{1}$ and vó $\sigma 0 \varsigma_{2}$. The first to attack his body is vó $\mathrm{o}_{1}$, which we can classify as erotic passion-a longing, a desire which Heracles feels for Iole, and which is eventually said to confuse the mind of the hero. The destructive consequences of his temporary lack of lucidity appear only to impact others. Triggered by such blind passion, the hero has destroyed the city of Oechalia and forgotten his own family and people (431-3). Yet, despite the evident state of alteration affect-

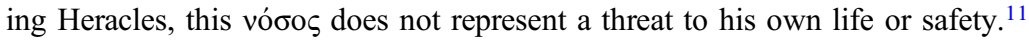

vó $\sigma 0 \varsigma_{2}$ is of a thoroughly different nature. It is not classifiable as a "natural phenomenon', since it is induced by the enchanted garment, and its destructive effects appear to affect Heracles alone. In what follows, I focus on the digression of this second and fatal

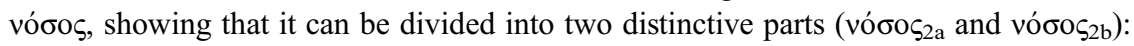
the first (vó $\sigma \varsigma_{2 \mathrm{a}}$ ) targets his skin and therefore constitutes the proof that the ointment smeared by Deianira on the robe is actually working; and the second (vó $\sigma \varsigma_{2 \mathrm{~b}}$ ) explicitly affects his mental state and signals that the disease is spreading around Heracles' body, moving from a superficial area (epidermis) to his most inner parts. While sacrificing on Mount Cenaeum, giving thanks to the gods for the propitious outcome of his last labour, Heracles wears the poisonous robe, which adheres tightly to his skin-this is the beginning of its magic-induced activity (765-9):

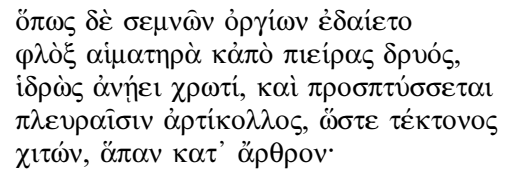

But when the bloodshot flame from the sacred offerings and from the resinous pine blazed up, the sweat came up upon his body, and the thing clung closely to his sides, as a carpenter's tunic might, at every joint.

Sophocles describes both the illness and the ritual as connected and proceeding at the same rate. He builds a vivid parallelism between the flame, acting on the offerings and the resinous pines, and the garment, seizing Heracles at his sides. ${ }^{12}$ The reader is already made aware at this point that the cause of Heracles' vóøos is the philtre, yet Sophocles chooses to stress the magic nature of the disease-first, by means of fire. ${ }^{13}$ A key element in erotic magic, fire acts as an erotic inductor in most ancient love spells. The actual blazing flame of the ritual was supposed to evoke and trigger the imaginary flame of love destined for the spell's victim. ${ }^{14}$

11 See lines 351-7. See also Thumiger (n. 1), 34: 'Heracles' passion for Iole is responsible for his deed of arms and the destruction of the city of Oechalia.'

12 On the parallel between the garment destroying Heracles' skin and the image of the resinous

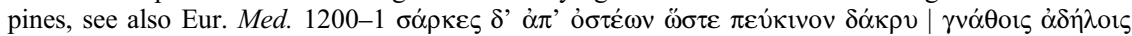

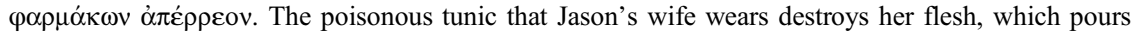
from her bones like resin from a pine.

13 On the magic nature of Deianira's intervention, see Faraone (n. 1), 115-35.

${ }^{14}$ See C. Faraone, Ancient Greek Love Magic (Cambridge, MA, 1999), 50: 'In both curses and erotic magic, for instance, Greeks destroyed wax effigies or other special materials in fire in hopes of projecting the pain and discomfort of fire onto the victim.' Segal (n. 5), 110 claims that the warming effect of the venomous garment evokes $\dot{\varepsilon} v \tau \varepsilon \theta \varepsilon \dot{\rho} \rho \alpha \nu \tau \alpha \mathrm{l} \pi \theta \theta \omega$ at line 368. On the erotic feeling experienced as warmth and sweat, see A.E. Peponi, 'Mixed pleasures, blended discourses: poetry, medicine and tragedy in Plato's Philebus 46-47c', ClAnt 21 (2002), 135-60, at 143; McNamara (n. 8), 315-16. 
As the flame of the altar begins to burn, the effects of the poisonous robe become simultaneously visible-Heracles' bodily temperature rises, and he sweats. As the robe clings to his skin, Heracles experiences what Sophocles describes as ỏ $\alpha \gamma \mu$ óc. Lloyd-Jones has interpreted the term as pain, and his translation of the passage runs as follows (769-71):

\section{$\hat{\eta} \lambda \theta \varepsilon \delta^{\prime}$ ỏ $\sigma \tau \varepsilon^{\prime} \omega v$

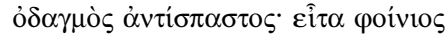

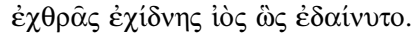

And a biting pain came, tearing at his bones; then a bloody poison like that of a hateful serpent fed upon him.

Yet, ỏ $\alpha \gamma \mu$ ó $\varsigma$ means not 'pain' but rather an 'itch, irritation' (LSJ s.v.). ${ }^{15}$ The noun is a

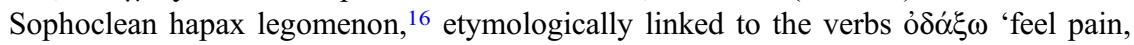

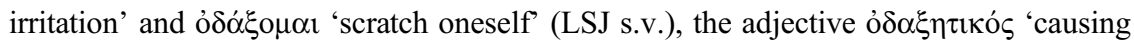
to itch' (LSJ s.v.) and the noun ó $\delta \xi \xi \eta \sigma \mu o$ s, which refers to a borderline feeling between

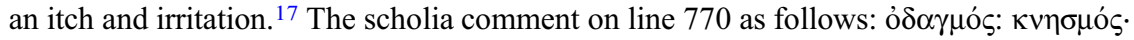

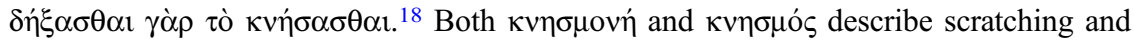
irritation (LSJ s.v.). If we suppose that the first feeling experienced by Heracles is an itch, rather than pain, we would have to reconsider the translation of the passage:

And a spasmodic itch came, tearing at his bones - then, the bloody poison of the terrible serpent [Hydra] fed upon him in this way.

The first effect of the enchanted garment on Heracles is a cutaneous rash. This represents visible proof that the erotic spell is working, seizing his body on a superficial level. Furthermore, it also evokes the long-held mythological tradition linking Heracles to skin diseases.

\section{HERACLES' $\Psi \Omega P A$}

According to a paremiographic source, Heracles was associated with a cutaneous pathology known as $\psi \omega \dot{\rho} \alpha$, which ancient texts unanimously describe as causing an intense itch. ${ }^{19}$ Zenobius' collection of proverbs refers to the disease, specifying that baths were deemed to be the most effective remedy against the so-called Heracles' $\psi \omega \dot{\rho} \rho \alpha$ :

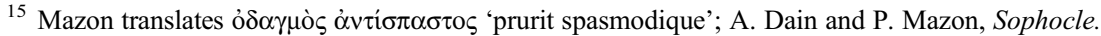
Tragédies. Tome 1: Les Trachiniennes, Antigone (Paris, 1955), 42.

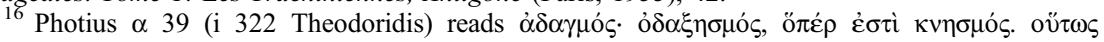

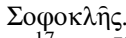

17 e.g. Hippoc. Aph. 3.25, where the noun expresses the gums' irritation when approaching dentition. See A.A. Long, Language and Thought in Sophocles. A Study of Abstract Nouns and Poetic Technique (London, 1968), 133-4 and Ceschi (n. 1), 70.

18 G.A. Xenis (ed.), Scholia vetera in Sophoclis Trachinias (Berlin and New York, 2010), 770a.2.

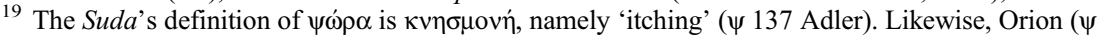
167.23 Sturz) seeks to explain the etymology of the word by connecting it to $\psi \hat{\omega}$, namely 'to scratch'. Lucian (Bis Accus. 34) refers to the pleasure experienced by people affected by $\psi \omega \dot{\rho} \rho \alpha$ when they scratch the diseased parts. As for clinical descriptions of $\psi \omega \omega \rho \alpha$, the Hippocratic Corpus (Aff. 35)

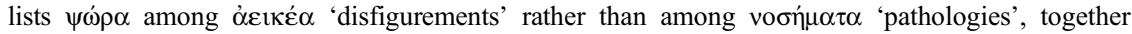
with $\lambda \varepsilon \dot{\varepsilon} \pi \rho \eta, \kappa v 1 \sigma \mu o ́ \varsigma, ~ \lambda \varepsilon \imath \chi \eta ิ v \varepsilon \varsigma, \dot{\alpha} \lambda \varphi o ́ \varsigma$ and $\dot{\alpha} \lambda \omega \dot{\pi} \varepsilon \kappa \varepsilon \varsigma$. See M. Grmek, Diseases in the Ancient
} 
Heracles' $\psi \omega \dot{\rho} \rho \alpha$ : it needs to be treated with the baths of Heracles. For Athena let Heracles have warm baths often as a relief from his labours, as the poet Peisander says in his Heracleia. ${ }^{20}$

Zenobius refers to Heracleia, the work of the seventh-century B.C.E. poet Peisander. ${ }^{21}$ Nevertheless, as discussed by von Staden, ${ }^{22}$ other versions exist, in which Athena is substituted either by Hephaestus ${ }^{23}$ or by the Nymphs. ${ }^{24}$ The link between skin diseases, Heracles and hot baths can also be found in other authors-as reported by both Strabo and Pausanias, cutaneous diseases were usually treated with baths, and the river Anigrus was particularly renowned for the healing properties of its waters:

In the mythical accounts, however, this [sc. the offensive odour of the river Anigrus] is attributed by some writers to the fact that certain of the Centaurs here washed off the poison they got

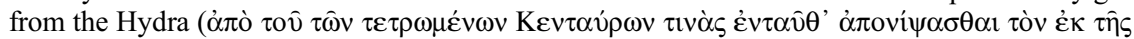
" $\Upsilon \delta \rho \alpha \varsigma$ ióv), and by others to the fact that Melampus used these cleansing waters for the purification of the Proetides. The bathing-water from here cures $\dot{\alpha} \lambda \varphi o_{s}, \lambda \varepsilon \dot{\kappa} \kappa \eta$ and $\lambda \varepsilon\left\llcorner\chi \eta \dot{\eta} v{ }^{25}\right.$

Strabo here links $\dot{\alpha} \lambda \varphi o ́ \varsigma, \lambda \varepsilon v ́ \kappa \eta$ and $\lambda \varepsilon \imath \chi \eta \dot{v}$, three cutaneous diseases described in medical texts as being similar to the so-called $\psi \omega \dot{\rho} \rho{ }^{26}{ }^{26} \mathrm{He}$ implicitly refers to Heracles and the related mythological tradition. His account on the healing properties of the river Anigrus' waters is explained more clearly by Pausanias:

Some Greeks say that Chiron, others that Pylenor, another Centaur, when shot by Heracles fled wounded to this river [sc. Anigrus] and washed his hurt in it, and that it was the Hydra's poison

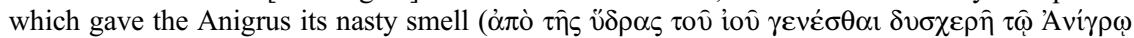
$\tau \eta \dot{v} v \sigma \mu \eta v)$. Others again attribute the quality of the river to Melampus the son of Amythaon, who threw into it the means he used to purify the daughter of Proetus. There is in Samicum a cave not far from the river, and called the Cave of the Anigrid Nymphs. Whoever enters it suffering from $\dot{\alpha} \lambda \varphi \cos _{\zeta}$ or $\lambda \varepsilon v \dot{\kappa} \eta^{27}$ first has to pray to the nymphs and to promise some sacrifice or other, after which he wipes the unhealthy parts of his body. Then, swimming through the river,

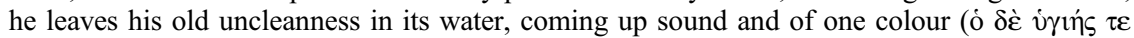

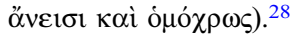

As reported by Pausanias, one of the possible reasons for the pungent smell of the river Anigrus may be related to Heracles. In particular, one of the Centaurs shot by him (either Chiron or Pylenor) was deemed to have washed his wounds in the Anigrus, infecting its waters with his blood and with Hydra's poison. The mention of Hydra's poison makes it clear that the shot that harmed the Centaur was inflicted with one of

Greek World (trans1. M. Muellner-L. Muellner) (Baltimore, 1989), 166: 'In a stationary-that is, chronic and not evolving-state, the skin's "leprous" appearance betokens neither abscession (apóstasis) nor disease (nósèma) but merely represents an aesthetic blemish (â̂schos).' The author

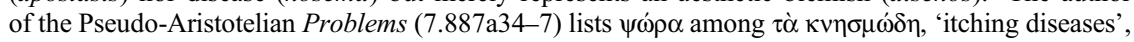
also specifying that it is an infective disease. Galen (De tumoribus praeter naturam 13 [K. 7.727]) explains that both $\psi \omega \dot{\rho} \alpha$ and $\lambda \dot{\varepsilon} \pi \rho \alpha$ are conditions arising from black bile, which uniquely affect the skin. If either affliction affects veins or flesh, then it is to be classified as коркívo

${ }^{20}$ Zen. 6.49.

${ }^{21}$ Fr. 7 West.

22 von Staden (n. 6), 146-7.

23 e.g. Ibyc. fr. 300 Page.

24 e.g. Diod. Sic. 4.23.1.

${ }^{25}$ Strabo 8.3.19.c346-7. Transl. H.L. Jones (Cambridge, MA, and London, 1927), slightly modified.

${ }^{26}$ See n. 19 above, in particular Hippoc. Aff. 35.

${ }^{27}$ In Pausanias there is no mention of $\lambda \varepsilon \imath \chi \eta ் v$, which features in Strabo's account.

${ }^{28}$ Paus. 5.1.5.10-11. Transl. W.H.S. Jones (Cambridge, MA, and London, 1926). 
Heracles' arrows, which were allegedly soaked in this venomous liquid. Centaur's blood mixed with Hydra's poison is the very same concoction which Deianira smears on Heracles' garment and which prompts the series of atrocious symptoms in the hero. Whereas a small amount of the poisonous concoction diluted in water was deemed beneficial for cutaneous diseases, as it peeled off the affected areas of the skin, direct contact with the substance for Heracles has an obnoxious effect.

The link between Heracles' poison and the poisoned Centaurs is mentioned by Sophocles in the final part of the tragedy. While Heracles gradually loses his lucidity, as a result of the agonizing torments of his vóбos running its course, Deianira acquires hers, as she realizes herself to be the cause of the atrocious pain of her husband, and eventually resolves to commit suicide. What prompts this act is her realization that the concoction she used on Heracles' robe may have been the same that had killed the Centaur Chiron (712-18):

For if I am not to prove mistaken in my judgement, I alone, miserable one, shall be his ruin; I know that the arrow that struck him tormented even Chiron, who was immortal, and it destroys all the beasts whom it touches (

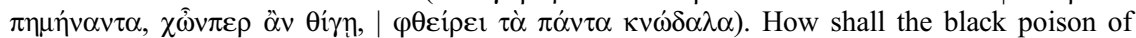
the blood, coming from the fatal wound, not destroy my husband also?

The two intertwined mythological accounts mentioned by Sophocles, and Strabo and Pausanias, thus suggest that the terrible ó $\delta \gamma \mu$ ó $\varsigma$ that afflicts Heracles after wearing the poisoned robe in Trachiniae can be identified as what was traditionally known as Heracles' $\psi \omega \dot{\rho} \alpha$. Both Strabo and Pausanias report an alternative version, according to which the power to peel off the diseased skin might have been due to Melampus. He was deemed to have thrown the unspecified means through which he managed to purify the raging daughters of Proetus in the river, causing an alteration in its waters. ${ }^{29}$ According to what was reported by Hesiod (Cat. frr. 132-3 Merkelbach-West), the daughters of Proetus were simultaneously affected by rage, sexual incontinence, and itch ( $\kappa v v$ os) and $\dot{\alpha} \lambda \varphi$ ó $^{3}{ }^{30}$ This last remark proves to be of particular interest. As I will show below, cutaneous conditions and sexual desire appear to be interwoven in Greek culture.

\section{UNDER HERACLES' SKIN}

Deianira's hope in the tragedy is to revive Heracles' passion for her, and for this purpose she gifts him with the poisoned garment-as Nessus told her, his poisoned blood is supposed to be a powerful love potion. Yet, the audience - and most probably Deianira herself $^{31}$-are left with a puzzling question, namely whether Nessus' blood is indeed a love

29 According to other versions of the myth, Melampus healed the raging girls at Sicyon (Paus. 2.7.8-9; Apollod. Bibl. 2.2.2). For a detailed account of the myth, see F. Marzari, 'Paradigmi di follia e lussuria virginale in Grecia antica: le Pretidi tra tradizione mitica e medica', I quaderni del ramo d'oro online 3 (2010), 47-74.

${ }^{30}$ For a discussion of the clinical picture of the daughters of Proetus and possible remedies, see M.F. Olivieri et al., 'Pharmacology and psychiatry at the origins of Greek medicine: the myth of Melampus and the madness of the Proetides', Journal of the History of Neuroscience 26 (2017), 193-215.

31 Faraone (n. 1), 123 claims that Deianira is well aware that poison is contained in the magic ointment, and her mistake rather consists in the dosage. Note the ambiguity of the word pó $\rho \mu \alpha \kappa o v$, meaning both 'enchantment', 'poison' and also 'cure', 'remedy' (LSJ s.v.). See McNamara (n. 8), 312. 
potion, just administered in the wrong proportions and therefore fatal, ${ }^{32}$ or whether it is merely a poison. According to the tradition mentioned by Deianira, the poison of Hydra reacting with the blood of Chiron caused such an intolerable condition in the immortal Centaur that he wished to be dead, and reached peace only when he was finally vanquished. ${ }^{33}$ The atrocious illness caused by the poison, then, manages to overtake even an immortal creature (cf. 443-4). Whereas the development of the torments in the cases of Chiron and Nessus is immediate, as their blood comes into contact with Hydra's poison, Heracles' case is different, as the philtre comes into contact with his skin.

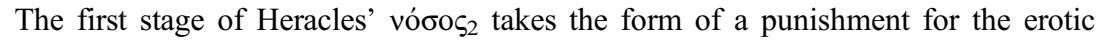
incontinence displayed by the hero. Although Deianira's attitude towards her adulterous husband is one of understanding, the same cannot be said of Sophocles. The choice to start the long list of symptoms with a cutaneous disease is particularly relevant. Itching and scratching were linked to love and erotic pleasure in Greek literature. ${ }^{34}$ Thus in Phlb. 46d-47a, for instance, Plato specifically chooses the image of scratching one's $\psi \omega \dot{\rho} \alpha$ to refer to bodily pleasure, which has also been read as a reference to erotic satisfaction. ${ }^{35}$ As underlined by Peponi, behind this figurative association is the idea that erotic acts are ultimately conceived as scratching or rubbing intimate bodily parts, and sexual pleasure is itself a sort of tickling or itching sensation. ${ }^{36}$ A clear description is found in Hippoc. On Generation 1.1:

The matter is as follows: vessels and cords from the whole body lead to the penis, and these, as

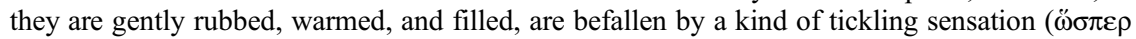
$\kappa v \eta \sigma \mu o ́ s)$, and from this pleasure and warmth arise in the whole body. ${ }^{37}$

A little further on in the text, at 1.4, the author says that the same applies to women:

${ }^{32}$ Ancient Greek literature provides evidence of women causing the death of their husbands through an overdose of love potions: Faraone (n. 1), 119. See also E. Eidinow, Envy, Poison, and Death: Women on Trial in Classical Athens (Oxford, 2018), 31: 'The figure of a woman standing trial for supernatural activities may have become a stock figure of the cultural imaginary of ancient Greek society.'

33 Apollod. Bibl. 2.5.4.

34 This is particularly evident in Hellenistic epigrams. See, for instance, Pomp. Anth. Pal. 7.219 (3965-6 Gow-Page, GP), where the torments of love are called $\kappa v i \sigma \mu \alpha \tau \alpha$, namely 'itches'. See also Mel. Anth. Pal. 12.126 (4464-9 Gow-Page, HE), where Erôs is said to scratch with the tips

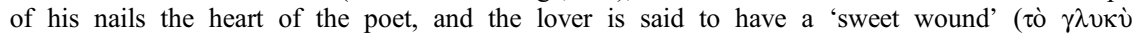
$\tau \rho \alpha \hat{v} \mu \alpha)$, burnt by 'fierce honey' ( $\lambda \alpha \dot{\beta} \rho \omega \mu \dot{\varepsilon} \lambda \imath \tau \imath)$.

35 See Peponi (n. 14), 152-3. On scratching and erotic pleasure in Plato, see Grg. 494d-e; also D. Frede, 'Disintegration and restoration: pleasure and pain in Plato's Philebus', in R. Kraut (ed.), The Cambridge Companion to Plato (Cambridge, 1992), 425-63; S. Benardete, The Tragedy and Comedy of Life: Plato's Philebus (Chicago and London, 1993), 194-7.

36 Peponi (n. 14), 153-5. She also refers to Arist. Gen. an. 1.18.723b34-724a and [Pr.] 4.878b.

37 Translations of Hippocrates' On Generation are by P. Potter (Cambridge, MA, and London, 2012). See I.M. Lonie, The Hippocratic Treatises "On Generation", "On the Nature of the

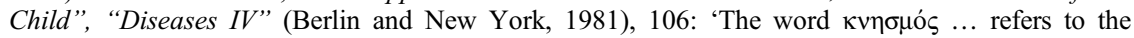
itch and irritation caused by a loss of small particles of tissue.' See also Arist. Gen. an. 1.20.728a9-14. According to V. Longhi ('L'amour médecin de l'âme dans le Phèdre de Platon [250e1-252c3]: rapprochements avec la Collection hippocratique', Études platoniciennes [online] 10 [2013], URL: http://journals.openedition.org/etudesplatoniciennes/376), this passage has much in common with the description of the effect of erotic desire on the soul in Pl. Phdr. 251a7-c5. In par-

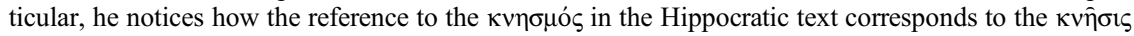
that the soul experiences when it becomes winged. 
Now in women, I assert that as their vagina is rubbed and their uterus moved during intercourse,

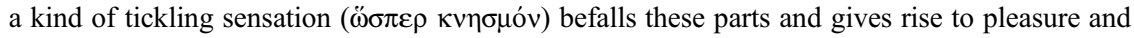
warmth in the rest of their body.

This association between scratching and erotic pleasure might also explain why skin conditions were also associated with an excessive sexual appetite. According to Aretaeus, ${ }^{38}$ for instance, the cutaneous disease called $\dot{\varepsilon} \lambda \dot{\varepsilon} \varphi \alpha \varsigma$ was also known as 'satyriasis', owing to specific characteristics displayed by the patients - namely the redness of their cheeks and the uncontrollable desire to have sexual intercourse. ${ }^{39} \dot{\varepsilon} \lambda \dot{\varepsilon} \varphi \alpha \varsigma$ was also named 'Heracles' disease', for the alleged might of the affection. It was believed that this cutaneous condition was caused by an excess of black bile, which is also one of the components of the lethal poison that is smeared on the robe. ${ }^{40}$

Thus the rashes on Heracles' skin, along with the intense itch, which were both associated with the idea of irretrievable need and erotic longing, are the first visible proof that the enchantment is working, by triggering an uncontrollable erotic desire in Heracles. The garment's activity on Heracles' body is described with erotic allusions- the robe is said to cling to his chest, seizing him at his flanks, and therefore giving him his final embrace instead of his lover Iole (767-9). ${ }^{41}$

The magic erotic induction caused by the robe constitutes the perfect punishment for Heracles' sexual incontinence, by turning his spontaneous erotic passion for Iole into a magic-induced longing. ${ }^{42}$ The philtre starts by provoking a strong itch and rash, consistent with the induced erotic passion that it was supposed to cause in the hero, and then proceeds by attacking his mind. However, the expected outcome of the enchanted garment ends up exceeding even Deianira's expectations, and soon irreparably damages Heracles' skin.

The second target of Heracles' vóбos are his lungs. ${ }^{43}$ The philtre is circulating around his body, as we learn that the hero is caught by pulmonary spasms (777-8:

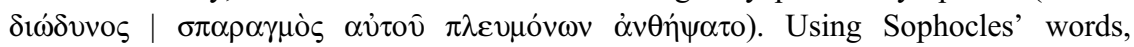
Heracles is seized by a $\sigma \pi \alpha \rho \alpha \gamma \mu$ ó, a term that expresses the idea of mangling and tearing. The same feeling that he experienced on his skin has moved to his bones and is now attacking his lungs. Yet, $\sigma \pi \alpha \rho \alpha \gamma \mu$ ó $\varsigma$ is also much more; it belongs to the Dionysian

38 Aret. De causis et signis diuturnorum morborum 2.13.

39 According to Aristotle (Gen. an. 4.3.768b30-6), satyriasis would be rather due to a bulk of unconcocted pneuma, which becomes settled in the animals' faces, giving them the typical appearance of a satyr. On satyriasis, see also C. Thumiger, 'A most acute, disgusting and indecent disease: satyriasis in ancient medicine', in C. Thumiger and P. Singer (edd.), Mental Illness in Ancient Medicine: From Celsus to Paul of Aegina (Leiden and Boston, 2018), 269-84.

${ }^{40}$ As Pozzi (n. 3), 583 n. 15 notices, the poison is a compound of two elements: Nessus' clotted

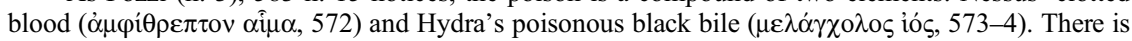
no mention in Sophocles of Nessus' sperm, which is listed among the ingredients of the poison by Diodorus Siculus (4.36.5).

${ }^{41}$ K. Ormand, 'More wedding imagery: Trachiniae 1053ff.', Mnemosyne 42 (1993), 224-7, at 225 : 'The robe, unlike either Deianira or Iole, has an absolutely exclusive relationship with Heracles' body.'

${ }^{42}$ Segal (n. 5), 111 points out that, even in the case of his passion for Iole, Heracles is said to be charmed (354-5). Yet, in this circumstance, it is Erôs himself who charmed Heracles-there is no magic involved.

${ }_{43}$ As R.B. Onians, The Origins of European Thought about the Body, the Mind, the Soul, the World, Time, and Fate (Cambridge, 1954²), 37 claims, the lungs were believed to be one of the main physical targets of Erôs. He refers to Sophocles, fr. 941 Radt, where Erôs is said to melt

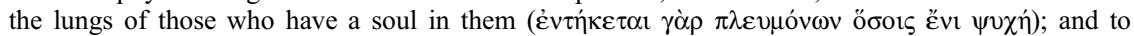
Hesychius ( $\pi 2530$ Hansen) and Photius $\pi 237$ (i 939 Theodoridis), who define lung disease

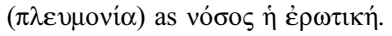


world, ${ }^{44}$ as this is also the name of the torture that Dionysus undergoes. ${ }^{45}$ The presence of $\sigma \pi \alpha \rho \alpha \gamma \mu$ ó $\varsigma$ with reference to Heracles catches the audience's attention, communicating at the same time that something unexpected is about to happen. In the following passages Heracles' behaviour will not comply with the well-known attitude of the hero, who will behave like a Maenad instead (786-96):

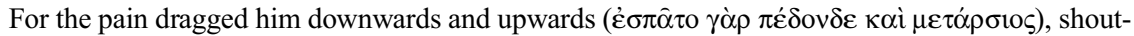
ing and screaming; and the rocks around resounded, the mountain promontories of Locris and the

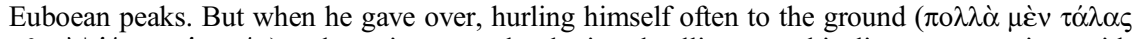
$\chi \theta o v i \mid$ pí $\pi \tau \omega v \dot{\varepsilon} \alpha v \tau o ́ v)$ and uttering many loud cries, dwelling upon his disastrous marriage with you, wretched one, and on how the alliance he had made with Oeneus had ruined his life, then he

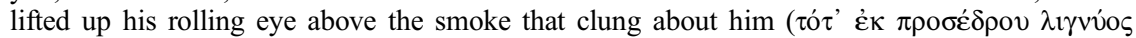

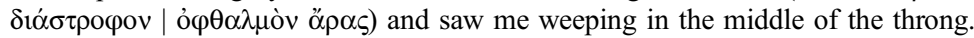

Sophocles makes the reader aware that the vóoos has moved on to the next level, affecting Heracles' mental state, with a rhetorical escamotage. He mentions the sacrifice again. Just as when the fire was blazing on the altar with the resinous pines (765-71) Heracles was seized by heat and consequently sweated, now that his mind is blurred, the fire has left its place to the thick smoke that surrounds him. From this point onwards, Heracles' consciousness seems to vanish and return inconsistently. He shows lucidity while asking his son Hyllus to move him out of the country, though the transport proves problematic because of Heracles' spasms, as Hyllus himself specifies in his speech

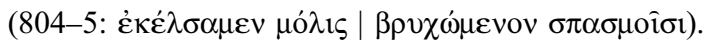

Unlike the first, the second stage of the disease develops thoroughly inside his body, and with increased ferociousness. After the philtre has mangled his skin, while it is circulating through his body, Heracles demonstrates the following symptoms: 1) sweat and altered bodily temperature, 2) difficulty breathing, 3) derangement, 4) spasms and altered motor skills and 5) rolling eyes. Although Sophocles makes it clear that the philtre has penetrated Heracles' innards and is now targeting them, he does not specify what sort of illness has struck him, choosing to maintain the vague expression vóøos instead. Consistent with what is found in the first part of the tragedy, we should expect the word vóбos here to refer to erotic passion too.

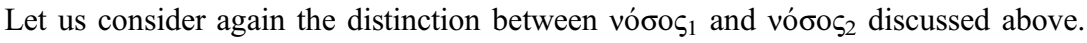
Despite having overcome many toils, Heracles is said to be defeated by a woman, with regard to both his erotic passion for Iole (488-9) and the ruin that will cause his death in the final part of the tragedy (1062-3). Whereas in the first case it is Lichas who describes Heracles as vanquished by his longing for Iole, in the second it is Heracles himself who claims to have been overpowered and destroyed by a woman. If the causes of both vófor are a woman and erotic feeling, why do they differ so much in their outcome?

We have already seen that whereas vó $\sigma o \varsigma_{1}$ is the product of a natural feeling that stemmed from Heracles, vó $\sigma 0 \varsigma_{2}$ is a magic-induced erotic disease, which we can define as unnatural. ${ }^{46}$ Although he is won over by Erôs, Heracles experiences longing for Iole

${ }^{44}$ M. Dillon, Girls and Women in Classical Greek Religion (London and New York, 2002), 140-3. On the term $\sigma \pi \alpha \rho \alpha \gamma \mu$ ó $\varsigma$, see also Long (n. 17), 134-5.

45 As Loraux (n. 1), 128-9 points out, 'Dionysos "the Lydian" was officially feminized', and Dionysus and Heracles are often linked (e.g. Ar. Ran. 45-7, 108-9).

${ }^{46}$ Faraone (n. 1), 126 claims that among the side effects of aphrodisiacs was also the feminization of the men, whose erotic desire increased at the expense of their masculinity, as 'an "unnatural" usurpation of male power'. 
as a man would do, actively pursuing the girl and expressing his passion as we would expect him to do-with aggressiveness and masculinity. As for vó $\sigma 0 \varsigma_{2}$ b Heracles first seeks to react to the grip of erotic passion in the only way he knows-by assaulting Lichas (772-82), and causing death and destruction. ${ }^{47}$ Yet, he soon realizes that vó $\sigma 0 \varsigma_{2 b}$ is different from the erotic disease he has experienced before. It is induced by the enchanted garment and does not stem naturally from him, but rather subjugates him and makes him its victim. ${ }^{48}$ What exactly does vó $\sigma o \varsigma_{2 b}$ consist of, and why is it so powerful as to destroy the hero? The very same symptoms from which he suffers point towards a typically feminine disease.

\section{UTERINE DISPLACEMENT AND HERACLES' FEMINIZATION}

Let us consider some passages from the Hippocratic treatise Diseases of Women (=Mul.) Book 2, concerning cases of womb displacement. Being allegedly able to move within the woman's body, the womb was believed to cause, among other symptoms, suffocation in the patients by blocking the passage of air (2.15 [124 L.]):

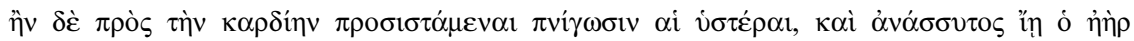

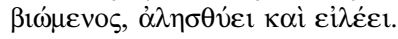

If the uterus moves close to a woman's heart and provokes suffocation, and her breath rushes upward under force, she will be restless and convulsed. ${ }^{49}$

By moving within the woman's body and hitting its inner parts, the womb was believed to affect most of her bodily functions. Restlessness and convulsions are only two of the possible consequences of uterine displacement-a little below in the text, it is explained how this disorder can also limit the motor skills of the sufferers:

If a woman's uterus does not remain in place, but moves at one time in one direction and at another time in another direction, this causes pains ... As long as she [sc. the patient] lies on her back it remains in place, but when she stands up or awakes from her sleep or bends over or makes any other movement, it protrudes, and often even when she is at rest (ö $\tau \alpha v \delta^{\prime}$

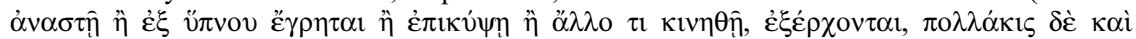

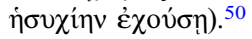

As the text above states, women suffering of womb displacement should avoid any movements - rest and sleep are absolutely recommended. Other remedies against this disorder are also listed in the treatise, among which are manipulation, odours and fumigation, and sexual intercourse, as mentioned at 2.18 (127 L.):

This [sc. that the uterus leans against the liver] happens most often to old maids and widows who have been widowed while still young and fertile. It also occurs frequently in women who have no children at all and are barren ... When the case is such, use your hand to press

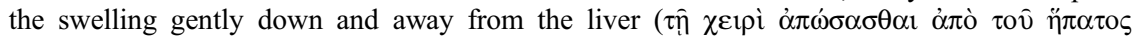

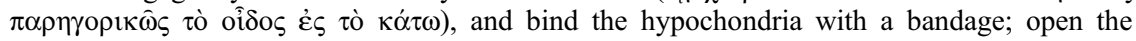

47 See Biggs (n. 1), 229.

48 See Pozzi (n. 3), 584, who claims that Heracles' feminization resides in having his heroic body penetrated by the erotic philtre smeared by his wife, which 'paints the very image of gender reversal'.

49 All the translations from Diseases of Women are by P. Potter (Cambridge, MA, 2018). On mental derangement as a consequence of uterine displacement, see also Mul. 2.24 (133 L.).

50 Mul. 2.40 (149 L.). See also Hippoc. Nat. mul. 44. 
mouth (sc. of the uterus) and infuse diluted very fragrant wine, when it is indicated, and apply ill-smelling agents against the nostrils; also fumigate below against the uterus with fragrant kinds of vapours ... Do this for the widow-but best would be for her to become pregnant;

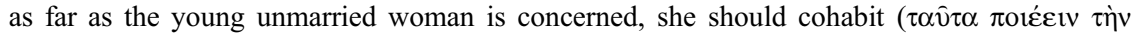

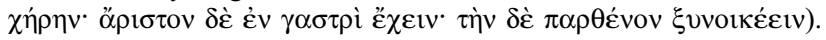

The excerpt above concerns cases of uterine displacement in which the womb hits the liver, and specifies that maids and widows are more prone to fall victim to it for their lack of intercourse. ${ }^{51}$ A similar explanation is provided in another account of the same pathology, at Mul. 1.7:

If suffocation suddenly occurs (ìv $\delta \dot{\varepsilon} \pi v i \xi \pi \rho o \sigma \tau \hat{~} \dot{\varepsilon} \xi \alpha \pi i v \eta \zeta$ ), this happens mainly in women that are not having intercourse with men, and more in older women than in younger ones: for their uterus is lighter ... When the uterus is lying against the liver and the hypochondrium, and thereby provoking suffocation, the patient turns the whites of her eyes up ( $\tau \dot{\alpha} \lambda \varepsilon v \kappa \dot{\alpha} \tau \hat{\omega} v$ $\dot{o} \varphi \theta \alpha \lambda \mu \hat{\omega} v \dot{\alpha} v \alpha \beta \dot{\alpha} \lambda \lambda \varepsilon \mathrm{r}$ ), and becomes cold; some immediately turn livid. She may also grind her teeth, salivate in her mouth. ${ }^{52}$

If the womb gets too light, owing to an excess of heat in the body, it will likely lose its stability and therefore move around the body. In addition to experiencing suffocation, the woman will also turn the whites of her eyes, become chilled and livid, grind her teeth and pour saliva from her mouth. Most importantly, the excerpt above confirms that women who neglect their biological role and avoid sexual intercourse and childbirth are more likely to experience womb displacement. But how does this female disorder relate to Heracles?

Let us take a closer look at vó $\sigma 0 \varsigma_{2 b}$ again. Heracles' symptoms can all be found in cases of womb displacement mentioned above, namely 1) alteration of the bodily temperature; 2) restlessness; 3) spasms and convulsions affecting motor skills: Heracles cannot walk and needs to be carried, although his spasms make the transportation difficult $(804-5) ; 534$ ) disquieted breathing and suffocation; 5) rolling eyes (whites of the eyes turned up). Shivering and teeth grinding are left out of Sophocles' description, as instead he makes a generic reference to Heracles' spasms. ${ }^{54}$

Heracles' disease manifests even more parallels with the uterine pathologies mentioned above. Just as in the passage from Mul. 2.40 quoted above, the patient is advised to lie on her back and sleep, as the womb tends to move particularly when she stands up or awakes, so Hyllus is warned by the doctor not to awaken his father, as this could

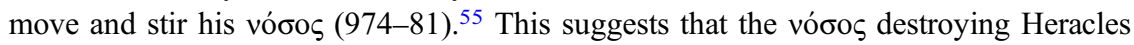
from within has the faculty to move around his body. Moreover, it is precisely its

51 Sexual abstinence was not the only alleged cause of womb displacement. The womb was 'liable to move in situations of menstrual suppression, exhaustion, insufficient food, sexual abstinence, and excessive dryness or lightness of the organ itself': H. King, Hippocrates' Woman: Reading the Female Body in Ancient Greece (London and New York, 1998), 214.

52 The passage also specifies that the patient resembles those suffering from Heracles' disease

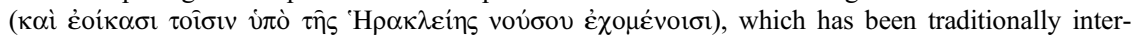
preted as a reference to epilepsy: von Staden (n. 6), 134-9.

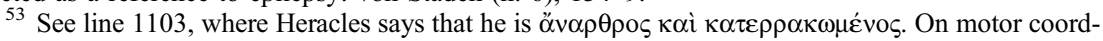
ination and its connection with emotional and mental state, see C. Thumiger, A History of the Mind and Mental Health in Classical Greek Medical Thought (Cambridge, 2017), 170-4.

54 Speechlessness is another common symptom in descriptions of uterine displacement (see e.g. Mul. 2.18 [127 L.]), which, understandably for the sake of the drama, is left out of Heracles' clinical picture.

${ }_{55}$ On rest as prescribed therapy in cases of womb displacement, see also Mul. 2.44 (153 L.). 
movement that causes Heracles' spasms. The adjective poı $\alpha$ ‘ s seems to hint at this same idea, namely 'wandering', assigned to the vóoos at $980 .{ }^{56}$ Thus, exactly as with the womb in the cases of uterine displacement mentioned above, Heracles' vó $\sigma o \varsigma$ can move around his body, causing him pain. Prompted by the doctor, Hyllus resorts to manipulation in a desperate attempt to soothe his father's pain, with manoeuvres that evoke those practised by ancient physicians in cases of wandering womb, as seen above. ${ }^{57}$ Every attempt, however, proves in vain (1020-35):

HYLLUS: I am putting my hand ( $\psi \alpha v \dot{\omega} \omega)$ to him; but neither from inside nor from outside can I manage to achieve a surgery that would cause him to forget his trouble! Such is the lot that Zeus assigns him.

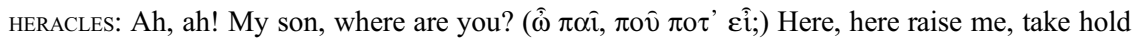

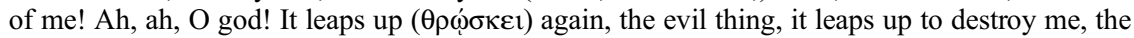
cruel plague, irresistible! Ah, ah, Pallas, again it does me outrage! Ah, my son, take pity on your father, draw a sword that none can blame and strike beneath my collarbone! ${ }^{58}$

To describe the effects of the disease on his body, Heracles uses the verb $\theta \rho \omega \sigma \kappa \omega$, which means both 'to attack' and 'to rape, mount, impregnate' (LSJ s.v.). Just as the wandering womb was believed to cause severe pain and suffocation, by stopping in the wrong parts of the body, so does Heracles' vóøos. Among other symptoms referred to previously, such as suffocation and altered mental function, dimming of vision is also mentioned frequently in cases of womb displacement. ${ }^{59}$ Heracles too seems to be affected by impaired or blurred vision, as he asks where Hyllus is, right when his son is touching Heracles' body, seeking to soothe his father's pain.

Heracles' vóбoৎ demonstrates striking similarities with uterine pathologies, as listed in Mul. Book 2, most of which might be dated as early as the middle decades of the fifth century B.C.E. ${ }^{60}$ Although there is no certainty about the time of composition of any of the three works, ${ }^{61}$ we know that Grensemann considered Mul. 1.7 to be supposedly composed later than most of Mul. Book 2 and Trachiniae, ${ }^{62}$ whereas a major part of Mul. Book 2 was approximately contemporary to Trachiniae. ${ }^{63}$ Thus both Sophocles'

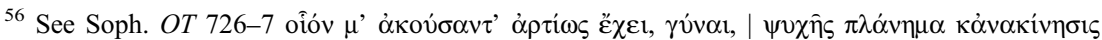
$\varphi \rho \varepsilon v \hat{\nu}$. To refer to Oedipus' irrational reaction, Sophocles assigns to his $\psi v \chi \eta$ the metaphor of wandering, which appears to be the male transposition of cases of wandering wombs, as shown in

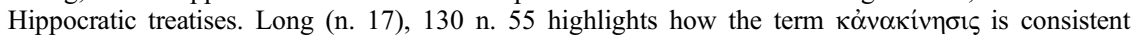

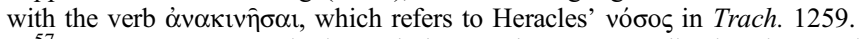

57 A.E. Hanson, 'Continuity and change: three case studies in Hippocratic gynecological therapy and theory', in S. Pomeroy (ed.), Women's History and Ancient History (Chapel Hill and London, 1991), 83-4; King (n. 51), 36-7.

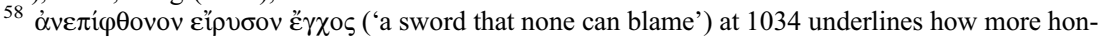
ourable and manlike it would be for Heracles to die wounded by a sword rather than among spasms caused by a feminine disease. As if to reiterate the inversion of roles between Heracles and Deianira, Sophocles lets her kill herself with a sword (925-31).

59 e.g. Mul. 2.16 (125 L.), 24 (133 L.), 92 (201 L.), 94 (203 L.).

${ }^{60}$ H. Grensemann, Knidische Medizin. Teil II. Versuch einer weiteren Analyse der Schicht A in den pseudohippokratischen Schriften De natura muliebri und De muliebribus I und II (Stuttgart, 1987), 66-72 and 90-1. Sections 2.15 (124 L.) and 40 (149 L.) would belong to the $A_{1}$ stratum, while 2.18 (127 L.) to the $\mathrm{A}_{2}$.

${ }^{61}$ On the dating of Hippocratic gynecological works, see H. Grensemann, Knidische Medizin. Teil 1. Die Testimonien zur ältesten knidischen Lehre und Analysen knidischer Schriften im Corpus Hippocraticum (Berlin and New York, 1975), 80-145. See also Hanson (n. 57), 73-110.

62 According to Grensemann (n. 61), 86-9, it belongs to the C stratum.

${ }^{63}$ On the (debated) issue of the dating of Trachiniae, see P.E. Easterling, Sophocles: Trachiniae 
renowned interest in medicine ${ }^{64}$ and the 'free circulation of ideas and recipes' between medical writers and collective traditions corroborate the possibility that the symptomatology of Heracles' feminization might be inspired by cases of uterine diseases. ${ }^{65}$

Heracles then goes on to describe his symptoms (1053-7):

It has clung to my sides ( $\pi \lambda \varepsilon v \rho \alpha \hat{\imath} \sigma)$ and eaten away ( $\beta \varepsilon \dot{\beta} \rho \omega \kappa \varepsilon)$ my inmost flesh, and lives with

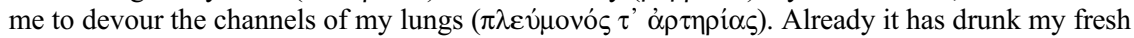

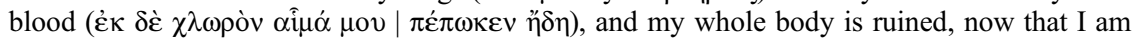
mastered by this unspeakable bondage ( $\left.\dot{\alpha} \varphi \rho \alpha \dot{\sigma} \sigma \tau \tau_{1} \pi \dot{\delta} \delta \eta\right)$.

Heracles describes the effects of the magic robe on his body. First, the garment has clung to his side and mangled his skin, and then the vóбos has seized his innards, targeting his lungs and drinking his fresh blood. This last remark suggests that Heracles' complexion is turning pale (a symptom he shares with Hippocratic women in Mul. 1.7).

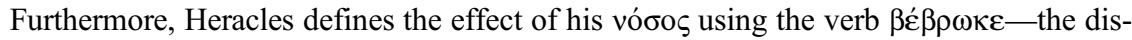
ease is 'devouring', 'biting' him. ${ }^{66}$ This remark is particularly interesting, as at Mul. 2.26 (135 L.), which describes a case in which the uterus dislocates towards a hip,

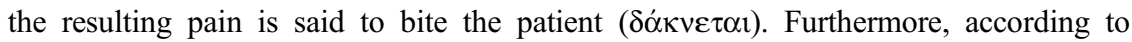
some magic erotic spells, the womb was meant to be similar to an animal, chewing and moving around the woman's body. ${ }^{67}$

He then moves on to express how his whole body has been subjugated by the magic spell cast by his wife, which he calls an ỏ $\varphi \rho \alpha \dot{\sigma} \sigma \omega \pi \varepsilon \dot{\varepsilon} \delta$, 'unspeakable bondage'. Further on, his condition is made clearer (1070-104):

Come, my son, bring yourself to do it! Pity me, pitiable in many ways, I who am crying out,

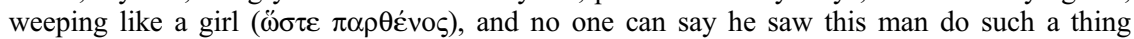
before, but though racked with torments I never would lament! But now such a thing has shown me as a womanish creature $(\theta \bar{\eta} \lambda v \varsigma)$... Again a spasm of torture has burned me, it has darted through my sides, and the ruthless devouring malady seems never to leave me with-

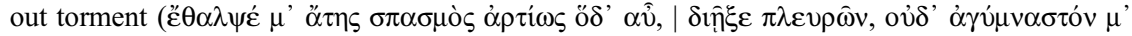

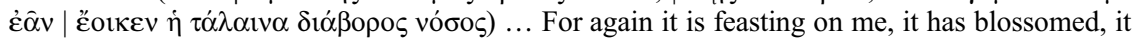

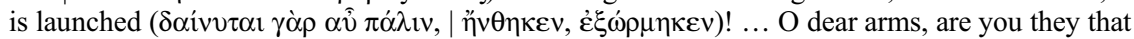
once by force subdued the dweller in Nemea ...? But now with joints unhinged and torn to rags

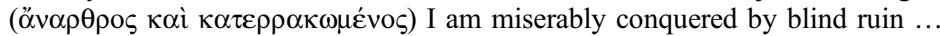

This last passage is particularly relevant. As Heracles himself states, the vóбoৎ has made him cry and weep like a $\pi \alpha \rho \theta \dot{\varepsilon} v o \varsigma$, and it has also turned him into a $\theta \hat{\eta} \lambda \nu \varsigma$, which Lloyd-Jones translates as 'womanish creature'. Even Heracles' language-register changes accordingly, as the hero seems to opt for a softer lexicon, more womanlike. Thus he says that his vóбos feasts, blooms and leaps (1088-9).

The question about the extent to which Heracles' metamorphosis into a $\theta \bar{\eta} \lambda \nu \varsigma$ should be considered realistic or rather figurative still puzzles scholars. Seaford has stressed the

(Cambridge Greek and Latin Classics) (Cambridge, 1982), 19-23 and P.J. Finglass, Sophocles: Ajax (Cambridge Classical Texts and Commentaries 48) (Cambridge and New York, 2011), 1-6.

${ }^{64}$ R. Mitchell-Boyask, 'Heroic pharmacology: Sophocles and the metaphors of Greek medical thought', in K. Ormand (ed.), A Companion to Sophocles (Malden, MA - Oxford - Chichester, 2012), 316-30.

65 Hanson (n. 57), 74.

66 On the devouring disease in the Hippocratic Corpus, see J. Jouanna, Greek Medicine from Hippocrates to Galen. Selected Papers (transl. N. Allies) (Leiden and Boston, 2012), 81-96, and

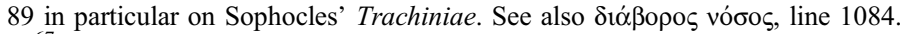

${ }^{67}$ e.g. PGM VII.260-71. 


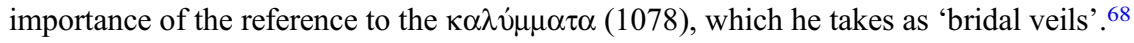
According to him, the expression evokes the practice known as $\alpha v \alpha \kappa \alpha \lambda \nu \pi \tau \eta \dot{\eta} \rho$, , the ritualistic unveiling of the bride that takes place at nuptial banquets. But the reference

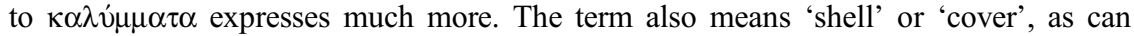
be found on fruit (LSJ s.v.). $\kappa \alpha \lambda u ́ \mu \mu \alpha \tau \alpha$ here acts as a shell, a cocoon beneath which Heracles' metamorphosis takes place.

Some scholars have gone further, and interpreted his symptoms as those of a woman in childbirth. ${ }^{69}$ Heracles is said to accomplish his metamorphosis from a man into a

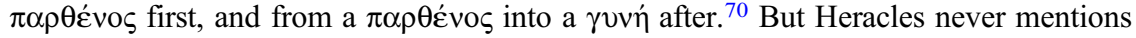

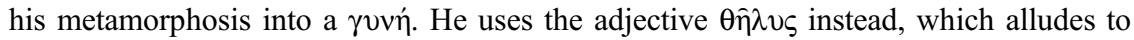
feminization more generally. Moreover, Heracles' insistence on his flanks ( $\pi \lambda \varepsilon v \rho \alpha \hat{\sigma} \sigma)$ is a key element in the development of his symptomatology. Loraux argues that Heracles' feminization evokes the pain of a woman in childbirth, but Heracles' pain is concentrated not around his belly but in his $\pi \lambda \varepsilon v \rho \alpha$ i. $^{71}$

According to Hippocractic treatises, painful $\pi \lambda \varepsilon v \rho \alpha i$ were among the symptoms used to diagnose cases of wandering womb. ${ }^{72}$ Furthermore, suffocation in pregnant women is extremely rare in Hippocratic literature-which reports only one casewhereas it features as one of the most common symptoms of uterine displacement. ${ }^{73}$ As a result of his feminization, Heracles develops an identity crisis, which evidently emerges when he refers to Hyllus as his true-born son, and asks him to disown his mother, whose role he would be ready to take over (1064-5). As Cawthorn notes, 'in Sophocles' Trachiniae, Heracles is emphatically feminised by suffering, and exhibits a type of body confusion. He becomes female, bearing a kind of femininity of the bodyself and a concomitant collapse of masculinity'. ${ }^{74}$

\section{CONCLUSIONS}

I do not intend to suggest that Heracles is actually growing a womb in his body, nor that he is becoming a woman. ${ }^{75}$ Instead, I argue that the magic erotic philtre has subjugated the hero, triggering a female reaction in him, as it makes him experience love and erotic longing with the same symptoms that a woman in need of sexual intercourse would display, according to Hippocratic treatises. The magic erotic induction sets off a spasmodic itch that pervades Heracles' body, culminating in his feminization, which I take as a mainly biological experience-Heracles is experiencing the typical symptoms of uterine displacement, yet in a male body.

${ }^{68}$ R. Seaford, 'Wedding ritual and textual criticism in Sophocles' "Women of Trachis"', Hermes

114 (1986), 50-9, at 57.

${ }^{69}$ Loraux (n. 1), 40.

${ }^{70}$ Cawthorn (n. 2), 86.

${ }^{71}$ Loraux (n. 1), 40 seeks to solve this inconsistency by claiming that 'Herakles, wounded in his side (or in the lung), feels pain throughout his entire thoracic cavity.'

72 e.g. Nat. mul. 8; also Mul. 2.19 (128 L.), 20 (129 L.), 25 (134 L.), 26 (135 L.), 31 (140 L.).

73 See Hanson (n. 57), 83. See Mul. 1.32, where suffocation is caused by the baby acting like a womb, and seeking moisture.

${ }^{74}$ Cawthorn (n. 2), 83.

${ }^{75}$ Here I disagree with Cawthorn (n. 2), 91. 
Heracles experiences erotic need in a passive manner, as a victim of the philtre, and not actively pursuing the objects of his erôs, as he was used to doing. ${ }^{76} \mathrm{He}$ is not master of his own body anymore, which is entirely subjugated by the action of the philtre. This is another point that Heracles shares with Hippocratic female patients. When it comes to sexual appetite, Hippocratic literature does not deem women to be in control of their own bodies. ${ }^{77}$ Likewise, in Heracles' case, the vó $\sigma o \varsigma$ generated by excessive desire is altering the condition of his own body, depriving him of any sort of control. This is the most suitable form of punishment that Sophocles could have devised against the womanizer par excellence-letting him experience erotic need from a female perspective.

University of Cambridge

CHIARA BLANCO

cb780@cam.ac.uk

${ }^{76}$ See lines 523-30, where Heracles actively engages in a ferocious fight with the river-god Achelous for Deianira, who passively witnesses the scene. See also the discussion in Wohl (n. 2), 17-29. By killing himself on the pyre and imposing the marriage of Hyllus and Iole in the final part of the tragedy, Heracles reaffirms his male superiority over the female characters.

${ }^{77}$ See L. Dean-Jones, 'The politics of pleasure: female sexual appetite in the Hippocratic Corpus', in D.C. Stanton (ed.), Discourses of Sexuality from Aristotle to AIDS (Ann Arbor, 1992), 51: 'The female sexual appetite described in the Hippocratic gynecology precludes directed desire and the exercise of self-control over the body's imperative to intercourse.' 